\title{
Identify the Effect of Supplementing Asparagus Racemosus for Buffalo on Milk Quality Related to Milk Yield and Composition
}

Birhanu Tsegaw ${ }^{1,2}$, Rita Singh Majumdar ${ }^{3}$

10.18805/ag.DR-1459

\begin{abstract}
Milk is produced by the mammary gland of mammals to feed their young ones. Milk is an important nutrient-rich beverage that benefits our health. This article aims to study the effect of Asparagus racemosus root powder on milk yield and milk composition. The experiment was performed to determine the milk yield and milk protein, fat, total milk solid, and milk acidity after using Asparagus racemosus as a food supplement. The animals were selected based on purposive sampling to select lactate buffalo to avoid or reduced the error. During the experiment, animals fed in three phases; control, treatment, and the residual phase. In control phase animal diet normal ration, whereas in the treatment phase, a buffalo was diet 120 gram of Asparagus racemosus root powder in addition to its normal diet per buffalo per day. While in the residual phase, the animal was diet only normal ration. Each phase has been 5 days. The Milk collected from lactating buffalo in three phases; control, treatment, and the residual period. Each period has been five day. We also measured milk yield per day per buffalo. About $50 \mathrm{ml}$ of milk was collected from each five buffalo every morning for 15 days. The data was analyzed through one way ANOVA and T-test using the procedure of statistical software. The result indicates that the diet was statistically significant effecting on milk yield at $5 \%(0.0196)$, protein at $1 \%(0.0113)$ and fat at $1 \%(0.0007)$ while the insignificant effect on milk acidity $p>30(0.3909)$ and total solid $p>80$ (0.8904). Therefore, feeding Asparagus racemosus, positively affects milk yield and milk protein and milk fat content.

Keyword: Asparagus racemosus root powder, Feed additive milk, Milk composition, Milk protein

Asian Journal Of Dairy and Food Research (2019)
\end{abstract}

\section{INTRODUCTION}

$\mathrm{M}$ ilk is a white liquid produced by the mammary gland of mammals to feed their young (Pehrsson, 2000). Milk contains a great variety of nutrients (proteins, carbohydrates, fats, minerals, and vitamins). The major species used for milk production are cattle, sheep, goats, buffalo, camels, etc. India is the largest milk-producing nation due to its thriving population per capita availability. In the past over 2 years, Milk shows a speedy improvement in production along with increasing the human population, urbanization traits, and rising family incomes and nutrient requirements (Turner and Davies, 2002). Therefore, the time has come when there is an urgent requirement for increasing milk quantity as well as its quality. However, the genetic and environmental factor affects the requirement of milk quantity and quality (Berhane and Singh, 2002). Time has come for force training to enhance awareness of the importance of hygienic milk production quantity-wise and quality-wise.

Therefore, to restore animal productivity and to optimize milk production for better profits, various herbal preparations, hormones, mineral supplements, and feed additives are important variable results. Now a day, herbal plants are widely used as animal feed additives, among these herbal Asparagus racemosus (Pawar \& Somkuwar, 2005). Asparagus racemosus is a woody climber growing to 1-2 m in length. According to Patel, et al., 2016) observed Asparagus racemosus are effective herbal galactogogue and its uses as a feed additive in dairy animals. Therefore, the objective of the study was to evaluate the effect of asparagus on the galactogogue activity in relation to milk yield and
1Department of Biotechnology, School of Engineering and Technology, Sharda University, Greater Noida, U.P., India

${ }^{2}$ Senior expert in Minister of Agriculture, Addis Ababa, Ethiopia

${ }^{3}$ Department of Biotechnology, School of Engineering and Technology, Sharda University, Greater Noida, India

Corresponding Author: Birhanu Tsegaw, Department of Biotechnology, School of Engineering and Technology, Sharda University, Greater Noida, U.P., India , Email: btsegaw5@gmail.com

How to cite this article: Birhanu, T. and Rita, S. (2019). Identify the Effect of Supplementing Asparagus Racemosus for Buffalo on Milk Quality Related to Milk Yield and Composition. Asian Journal Of Dairy and Food Research, 38(3): 169-177.

Source of support: Nil.

Conflict of interest: None

Submitted:29-06-2019 Accepted:27-09-2019 Published: 01-11-2019

its composition, Identify the effect of Asparagus racemosus root powder (ARRP) on milk yield and milk composition, Therefore, this study will contribute to fill the gap milk yield and the required nutrient intakes and knowledge of the effect between milk production and herbal.

\section{Materials AND methods}

The experiment was conducted at private dairy farm on Brondo village in Greater Noida in India. Analysis of the samples was carried out in Sharda University Biotechnology Laboratory Research Centre in Greater Noida India from February to May 2019. During the investigation of the experiment have been the following performed; Select 
lactated buffalo the same age and the same lactation period through purposive sampling, supplemented the ARRP with standard concentrates to meet their nutritional requirements, monitoring of daily milk yield through daily data record, analysis of Chemical composition and analyzed through statistical software.

Feeding of experimental animals; the experimental buffalo was fed and kept as separately in the same loose housing system. As the Table 1 show, the animals were divided into five. Feeding standard to meet the requirement of nutrients for 15 days. The amount of herbal ARRP fed was given 120 grams for 5 days mixed with other standard ration (during the treatment phase). The root powder bought from the market authenticated. The animals were feeding in a three-phase control phase (before supplementing ARRP or pre-treatment phase), treatment phase (during feeding ARRP), residual effect phase(after stopped feeding ARRP). The animals were fed twice daily at around 7 a.m. and 5 p.m.

\section{Methods of analysis, monitoring of milk yield and Chemical analysis}

The experiment was tested to determine the milk composition of protein, fat, total milk solid and milk acidity using according to IOS 707. The animals were selected based on purposive
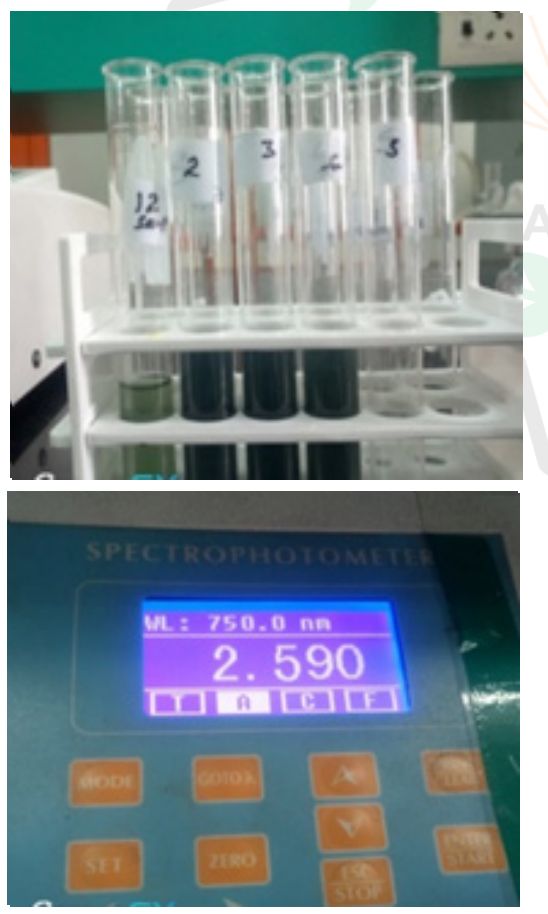

Figure 1: Determine protein content using OD reading in a spectrophotometer

Table 1: The characteristics of experimental animals

\begin{tabular}{lllll}
\hline Number & Type of buffalo & Age in year & Lactation period & $\begin{array}{l}\text { Amount of asparagus supplemented per day per } \\
\text { animal in gram }\end{array}$ \\
\hline 1 & M-1 & 7 & First & 120 \\
2 & J-2 & 7.2 & First & 120 \\
3 & B-3 & 6.9 & First & 120 \\
4 & MU-4 & 6.9 & First & 120 \\
5 & L-5 & 9 & First & 120 \\
\hline
\end{tabular}

sampling to select lactate buffalo in order to avoid or reduced the error. Lactated buffalo were milked twice a day and recorded every day throughout the experimental length of 15 days. The Milk collected from lactating buffalo under 3 phases; control, treatment and the residual period (each phase 5 day) and measured milk yield in litter per day per buffalo for 15 day. The sample was taken $50 \mathrm{ml}$ of milk from each five buffalo every morning for 15 day. The experimental animals had been selected lactating at list one month up to three month.

Determine the Protein contents: Lowry method it is a biochemical assay for determining the total level of protein in a solution and one of the most venerable and widely-used protein assays. The total protein concentration is exhibited by a colure change of the sample solution in proportion to protein concentration (Lowry, 1951). A variety of compounds interfered with the Lowry procedure

Prepared the reagents of A) BSA stock solution $1 \mathrm{mg} \mathrm{ml}^{-1}$, B) $2 \% \mathrm{Na}_{2} \mathrm{CO}_{3}$ in $\left.0.1 \mathrm{~N} \mathrm{NaOH}, \mathrm{C}\right) 1 \%$ Sodium-Potassium Tartrate in $\mathrm{H}_{2} \mathrm{O}$, D) $0.5 \% \mathrm{CuSO}_{4} .5 \mathrm{H}_{2} \mathrm{O}$ in $\mathrm{H}_{2} \mathrm{O}$. The mixed solution in 1 beaker from $\mathrm{B} 28 \mathrm{ml}, 1 \mathrm{ml}$ from $\mathrm{C}$ and $\mathrm{D}$. finally 1 part FolinCiocalteu:

Procedure: as Figure 1 shows, Prepared 6 test tubes in one standing, out of this five different ( $M, J, B, M U, L, B S A)$ sample
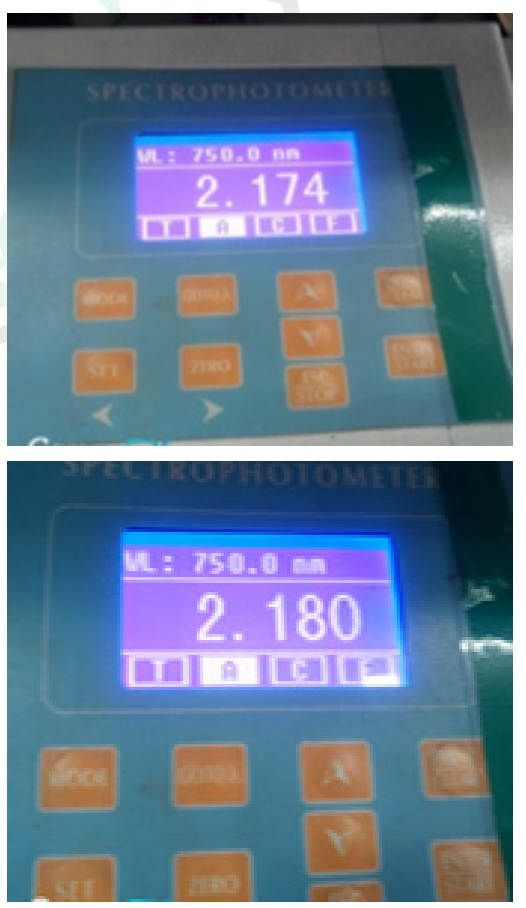
of milk and 1 BSA standard test tube. Added $0.05 \mathrm{~mL}$ sample in each 5 test tubes and then $0.05 \mathrm{~mL}$ BSA standard in other test tube and following $9.950 \mathrm{~mL}$ of distilled water. Then added $5 \mathrm{~mL}$ of the mixed reagent shook well and incubated for 10 minutes in the dark at room temperature. After this Added $1 \mathrm{~mL}$ of Folin-Ciocalteu with water again shook well and incubated in the dark for further 30 minutes. All these reagents were prepared in advance and stored under darkroom conditions (Lowry, 1951). Measured the absorbance at $750 \mathrm{~nm}$. As the Figure shows, the result estimated the amount of protein content and OD reading at three phases.

\section{Determine the fat content}

As the Figure 2 shows, an empirical method and reproducible results can be obtained. The milk is mixed with sulphuric acid and isoamyl alcohol in a special Gerber tube, permitting dissolution of the protein and release of fat BIS, (1981) and AOAC., (1990). The reagent was used Sulphuric acid, Iso-amyl alcohol, Gerber butyrometer, Geber's centrifuge, pipette, and unit of glass (F.A.O., 1961).

The Procedure of fat content was measured $10 \mathrm{~mL}$ of sulphuric acid into a butyrometer tube and mixd the 10.75 $\mathrm{mL}$ of milk sample gently but thoroughly and fill the milk pipette above the graduation line then add $1 \mathrm{~mL}$ of Amyl alcohol, close with a lock stopper, then formed three distinct layers, shake until homogeneous, inverting it for complete admixture of the acid. Insert the butyrometer into Geber's centrifuge at a speed of $1100 \mathrm{rpm}$ for 5 minutes. Remove the butyrometer tubes and place into standing. Finally, read the upper and lower meniscus along the neck of the butyrometer and recoded the difference between the two meniscuses of the fat column gave a percentage of fat.

Determination of total solids content (Gravimetric method) percentage as the Figure 3 shows were determined by the oven-dried method. The required material has been used analytical Balance, Desiccator, Boiling water, Drying oven, flat bottomed dishes (stainless steel, nickel or aluminium) and Water bath. Total solids \% was calculated by the following formula (ISO, 1989).

Procedure: Measured the $5.2 \mathrm{~mL}$ of milk sample into flat dishes, Transfer sample to a beaker, warm slowly to $35^{\circ}-40^{\circ} \mathrm{C}$ on a water bath with careful mixing to incorporate any cream adhering to the sample. Then add $5 \mathrm{~mL}$ of a prepared sample, place the lid on the dish, and weigh again. Heat a dish with its lid alongside in the drying oven for 1 hour. Allow the dish to cool and weigh to the nearest $0.1 \mathrm{mg}$. Place the lid on the dish and immediately transfer to the desiccator. Finally, measure each dish.
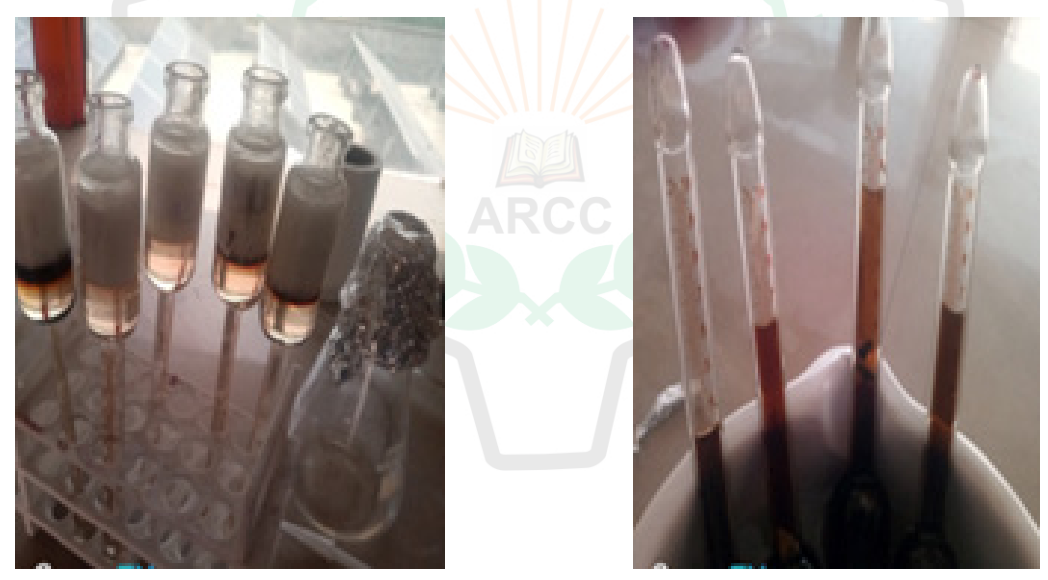

Figugre 2: Determine milk fat content
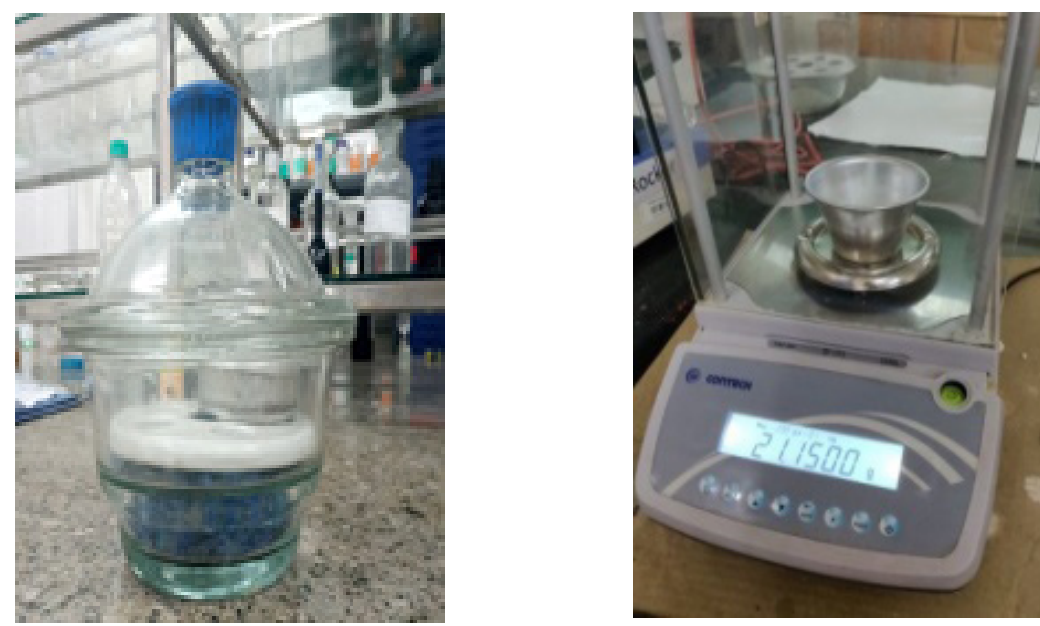

Figure 3: Determine total milk solid content 


$$
\text { Total solid \% }=\frac{\text { Weight of dried sample }}{\text { Weight of milk sample }} \times 100
$$

Determination of milk acidity used; as Figure 4 shows that determined by titrating a known volume of milk with standard alkali to the point of an indicator of phenolphthalein (AOAC, 1990). As the Figure 2.B shows were determined the milk acidity. The required material; $10 \mathrm{ml}$ pipette, $1 \mathrm{ml}$ pipette, conical flask, burette, glass rod, phenopthalin indicator, sodium hydroxide solution.

Procedure: The procedures of milk acidity $9 \mathrm{~mL}$ of the milk sample measured into the conical flask (AOAC, 1990). $1 \mathrm{~mL}$ Phenopthalein is added. Then added slowly into burret $0.1 \mathrm{~N}$ sodium hydroxide, until a faint pink color appears. The number of $\mathrm{mL}$ of sodium hydroxide solution divided by 10 expresses the percentage of lactic acid.

The data was analyzed through one way ANOVA modal using the procedure of statistical software version 14 (Snedecor and Cochran, 1989). The data analyzis the use of percentages, means, and standard deviations, used to explain the basic characteristic or comparing the effect of ARRP on milk yield and milk composition.

\section{Results and discussion}

Effects of Asparagus racemosus root powder on milk yield, as Table 3 shows that the overall average amount of milk yield in the control phase, treatment phase, and residual phase were 9.1, 9.95, and 9.45, respectively litter of milk given by buffalo. While the difference between the treatments over control, the result indicated 0.85 (8\%) milk yield was increased during the animal feeding of ARRP per day per buffalo. While in each lactated buffalo milk yield produced was increased by $8 \%$, $10 \%, 6 \%$, and $7 \%$ on buffalo $\mathrm{M}-1, \mathrm{~J}-2, \mathrm{~B}-3$, and $\mathrm{L}-5$, respectively whereas MU buffalo was not increased milk yield.

Therefore in order to examine the overall effect of supplementing ARRP ration on milk yield, the experimental buffalo milk shows Table 4. Analysis of variance showed that the effect of ARRP diet on milk yield was statistically significant at 5\% $(P<0.05)$ probability level and positive
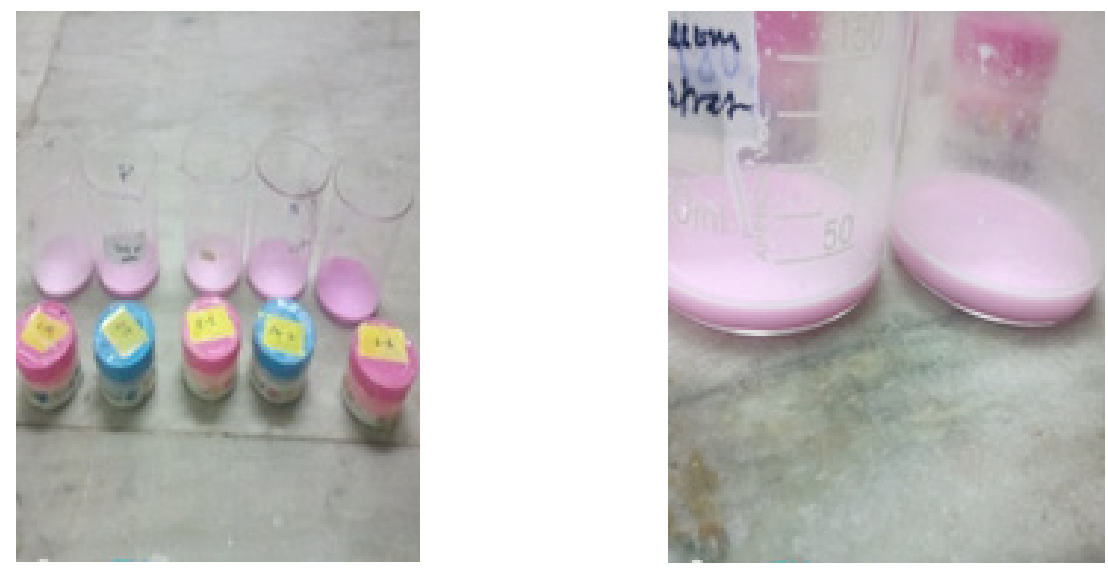

Figure 4: Test milk acidity

Table 3: The mean value of milk yield in control, treatments and residual phase

\begin{tabular}{|c|c|c|c|c|c|c|}
\hline \multirow[b]{2}{*}{ No } & \multirow[b]{2}{*}{ Buffalo } & \multicolumn{5}{|c|}{ The average amount of milk in litter per day per buffalo } \\
\hline & & Control & Treatment & Residual & Difference $b / n T-C$ & $\begin{array}{l}\text { Incremental by } \\
\text { percentage }\end{array}$ \\
\hline 1 & M-1 & 10.17 & 11 & 10.725 & 0.83 & $8 \%$ \\
\hline 2 & $\mathrm{~J}-2$ & 6.27 & 6.9 & 6.8 & 0.63 & $10 \%$ \\
\hline 3 & B-3 & 8.43 & 8.9 & 8.575 & 0.47 & $6 \%$ \\
\hline 4 & MU-4 & 8.57 & 8.6 & 8.525 & 0.03 & Ns \\
\hline \multirow[t]{2}{*}{5} & $\mathrm{~L}-5$ & 12.27 & 13 & 12.75 & 0.73 & $7 \%$ \\
\hline & Total & 9.1 & 9.95 & 9.45 & 0.85 & $8 \%$ \\
\hline
\end{tabular}

Table 4: Analysis the effects of Asparagus racemosus root powder on milk protein concentration through ANOVA one way and T-test

\begin{tabular}{|c|c|c|c|c|c|c|c|c|}
\hline \multirow[b]{2}{*}{ No } & \multicolumn{4}{|c|}{ ANOVA one way } & \multicolumn{4}{|l|}{ T-test } \\
\hline & Buffalo & F-value & $p$-value & Sig & Milk character & t-value & P-value & Sig \\
\hline 1 & $M-1$ & 21.7 & 0.0004 & $* * *$ & & & & \\
\hline 2 & $\mathrm{~J}-2$ & 3.46 & 0.077 & * & & & & \\
\hline 3 & $B-3$ & 3.9 & 0.0603 & * & Milk protein & 4.4461 & 0.0110 & $* * *$ \\
\hline 4 & MU-4 & 0.66 & 0.5405 & - & & & & \\
\hline 5 & $\mathrm{~L}-5$ & 3.93 & 0.0501 & $* *$ & & & & \\
\hline
\end{tabular}

***** and * indicates statistically significant at $1 \%, 5 \%$ and $10 \%$ significance level respectively. 
impact of milk yield. While in each buffalo supplementing herbal fed with ration on milk yield was statistically significant $M-1$ at $1 \%(p=0.0004), J-2$ at10 \% $(p=0.077), B-3$ at $10 \%$ $(p=0.0603)$ and $L-5$ at $5 \%(p=0.050)$ at different level that means the effect of supplemented was positively impact on milk yield. Whereas the $p$-value of MU-4 buffalo $(p=0.5405)$ indicated there was an insignificant effect on milk yield, that mean there was no relation between the ARRP and the milk yield. The value of $p$ is $(p>0.05)$. Therefore to conclude the effect ARRP of treatment on milk yield more statistically significant at $5 \%$ (0.0196) as compared to control.

As Figure 5 graphical data display, the blue color bar shows that the effect of the control phase (before supplementing ARRP with normal diet), which means the amount of milk produced from lactated buffalo, milk yield was lower than of the treatment. While the red color indicated that the effect of treatment (during supplementing ARRP with normal diet) slightly increases or the bar is bigger than the control and residual phase. Whereas the green color indicates residual effect slightly decreased the milk yield than of the treatment due to limit the diet of ARRP.

\section{Effects of Asparagus racemosus root powder on milk protein content}

To determine the effect of supplementing Asparagus racemosus root powder for buffalo on milk protein concentre at the time of feeding under the three phases; control phase, treatment phase, and residual effect phase. As table 5 shows that the overall average amount of milk protein found in the control phase, treatment phase, and residual phase were $1.841,2.776$, and 2.029 , respectively protein concentration in 0.5 grams of milk. While in each buffalo due to the effect of supplementing ARRP the milk protein concentration increased by $\mathrm{M}-1=61 \%$ (1.009), B-3 = 146\% (1.608), MU-4 = $32 \%(0.68)$ and $\mathrm{L}-5=18 \%(0.441)$ as compared to controls. Whereas J-2 (0.72) animals had not increased the milk proteins yield. While the difference between the treatments over control, the result indicated 0.93 (51\%) protein concentration in 0.5 gram of milk increased during the animal feeding of ARRP.

The analysis of variance data revealed a more significant effect of supplementing ARRP (during the treatment) on daily milk fat content, and is presented in table- 6 . The overall result indicates that feeding ARPP was statistically highly

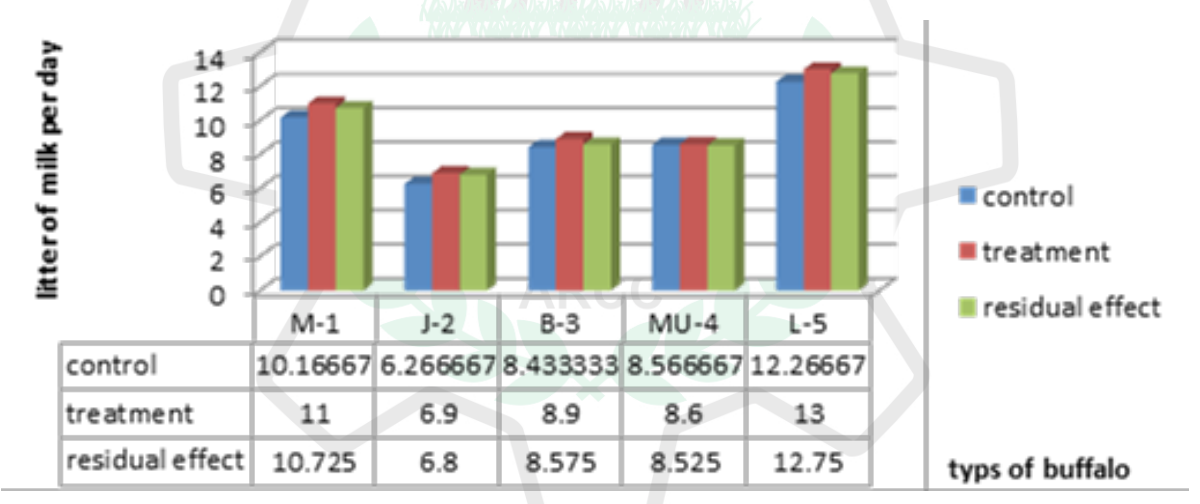

Figure 5: Effects of supplementing Asparagus racemosus on milk yield

Table 5: The mean value of milk protein in control, treatments and residual phase

\begin{tabular}{llllll}
\hline \multirow{2}{*}{ Breed } & \multicolumn{5}{l}{ Mean value of protein concentration in } \\
\cline { 2 - 6 } & Control & Treatment & Residual & difference & Percentage \\
\hline M-1 & 1.662 & 2.671 & 2.12 & 1.009 & $61 \%$ \\
J-2 & 2.08 & 2.8 & 2.149333 & 0.72 & $35 \%$ \\
B-3 & 1.105 & 2.713 & 1.982333 & 1.608 & $146 \%$ \\
MU-4 & 2.1505 & 2.83 & 2.045667 & 0.6795 & $32 \%$ \\
L-5 & 2.448 & 2.889 & 1.967 & 0.441 & $18 \%$ \\
Mean & 1.84137 & 2.77575 & 2.02875 & 0.934375 & $51 \%$ \\
\hline
\end{tabular}

Table 6: Analysis the Effects of Asparagus racemosus root powder on milk protein through ANOVA one way and T-test

\begin{tabular}{|c|c|c|c|c|c|c|c|c|}
\hline \multirow[b]{2}{*}{ No } & \multicolumn{4}{|c|}{ ANOVA one way } & \multicolumn{4}{|l|}{ T-test } \\
\hline & Buffalo & F-value & $p$-value & Sig & Milk character & $t$-value & P-value & Sig \\
\hline 1 & M-1 & 10.62 & 0.0158 & ** & & & & \\
\hline 2 & $\mathrm{~J}-2$ & 1.09 & 0.4047 & Ns & & & & \\
\hline 3 & B-3 & 8.94 & 0.0223 & $* *$ & Milk protein & 4.4461 & 0.0110 & $* * *$ \\
\hline 4 & MU-4 & 4.42 & 0.0783 & $*$ & & & & \\
\hline 5 & $L-5$ & 84.41 & 0.0001 & $* * *$ & & & & \\
\hline
\end{tabular}


significant at $0.0196(P<0.05)$ probability level and positive effect of milk yield. Based on each sample through the use of analysis of variance, the result was indicates that the effect of supplementing ARRP on milk protein was statistically significance at $M-1(p=0.0158), B-3(p=0.0223), M U(p=$ $0.0783)$ and $L-5(p=0.0001)$ significance level. Means there was correlation between the supplemented and milk protein yield increased. Whereas the $\mathrm{J}-2$ value of insignificance $(P>0.1)$ there was no relation between the treatments over control. That means there is no effect between the treatments over control Therefore to conclude the effect ARRP of treatment on milk protein yield more statistically significant at $1 \%(0.0110)$ level as compared to control.

As Figure 6 graphical data display The blue colour bar shows that the effect of control phase (before supplementing ARRP with normal diet) that means the amount of milk protein concentration lower than the treatment bar. While the red colour indicated that the effect of treatment on milk protein concentration (during supplementing ARRP with normal diet) slightly increase or the bar is bigger than the control and residual phase. Whereas the green colour indicates residual effect slightly decreased the milk protein concentration than of the treatment, Due to limit the diet of Asparagus racemosus root powder.

\section{Effects of Asparagus racemosus root powder on milk fat content}

To determine the effect of supplementing Asparagus racemosus root powder for buffalo on milk fat at the time of feeding under the three phases; control phase, treatment phase and residual effect phase. As the table-7 result indicates that the overall average amount of milk fat per buffalo per day was increased by $14 \%$ of milk fat. On the basis of average of milk fat contain before supplementing the ARRP, the milk fat contain was $5.28 \%$ of milk fat while after feeding the average amount milk fat contain per day was increased by $6 \%$ of milk fat.

The overall average amount of milk fat between the treatments and control the result increased by 0.72 of milk fat. While the incremental (difference) milk fat among the treatment over control the result was indicated milk fat increased by $\mathrm{M}-1=11 \%(0.5), \mathrm{J}-2=14 \%(0.7), \mathrm{B}-3=12 \%(0.65)$ and $\mathrm{L}-5=17 \%(0.95)$ as compared to controls.

Table 8 shows analysis of variance data revealed more significant effect of supplementing Asparagus racemosus root powder (during the treatment) on daily milk fat content. The overall result indicates that feeding Asparagus racemosus root powder was statistically highly significant at $1 \%(P<0.01)$ probability level and positively effect of milk yield. While

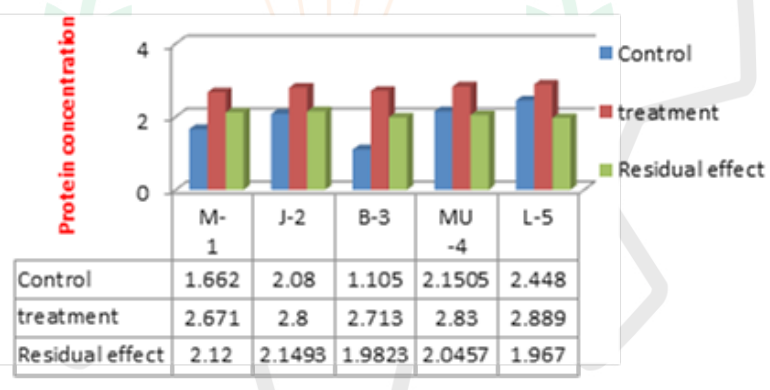

Type of Buffalo

Figure 6: Effects of Asparagus racemosus root powder on milk protein concentration

Table 7: The mean value of milk fat in control, treatments and residual phase

\begin{tabular}{|c|c|c|c|c|c|}
\hline \multirow[b]{2}{*}{ Breed } & \multicolumn{5}{|c|}{ Mean value of milk fat in percentage per day per sample } \\
\hline & Control & Treatment & Residual effect & Difference & Percentage \\
\hline M-1 & 4.5 & 5 & 4.7 & 0.5 & $11 \%$ \\
\hline $\mathrm{J}-2$ & 5.1 & 5.8 & 5.25 & 0.7 & $14 \%$ \\
\hline B-3 & 5.35 & 6 & 5.35 & 0.65 & $12 \%$ \\
\hline $\mathrm{MU}-4$ & 5.2 & 6 & 5.1 & 0.8 & $15 \%$ \\
\hline L-5 & 6.25 & 7.2 & 6.35 & 0.95 & $17 \%$ \\
\hline Mean & 5.28 & 6 & 5.35 & 0.72 & $14 \%$ \\
\hline
\end{tabular}

Table 8: Analysis the Effects of Asparagus racemosus root powder on milk fat content through ANOVA one way and -test

\begin{tabular}{|c|c|c|c|c|c|c|c|c|}
\hline \multirow[b]{2}{*}{ No } & \multirow[b]{2}{*}{ Buffalo } & \multicolumn{3}{|c|}{ ANOVA one way } & \multicolumn{4}{|l|}{$t$-test } \\
\hline & & F-value & $p$-value & Sig & Milk character & $t$-value & $P$-value & Sig \\
\hline 1 & $M-1$ & 6.24 & 0.0589 & * & & & & \\
\hline 2 & $\mathrm{~J}-2$ & 14.81 & 0.0142 & $* *$ & & & & \\
\hline 3 & B-3 & 2.7 & 0.1811 & Non & Milk fat & 9.5787 & 0.0007 & $* * *$ \\
\hline 4 & MU-4 & 3.14 & 0.1512 & $* *$ & & & & \\
\hline 5 & $L-5$ & 55.51 & 0.0012 & $* * *$ & & & & \\
\hline
\end{tabular}


in each buffalo supplementing herbal fed with ration on milk fat content was statistically significant $\mathrm{M}-1$ at $10 \%$ $(p=0.0589), J-2$ at $5 \%(p=0.0142), M U-4$ at $5 \%(p=0.1512)$ and $\mathrm{L}-5$ at $1 \%(\mathrm{p}=0.0012)$ significance level. Means the effect of supplemented was positively impact on milk fat content. Whereas the $p$-value of $B-3(p=0.1811)$ indicated that there was insignificant effect on milk yield that mean there was no relation between treatment and fat.

The milk acidity data was recorded during the treatment period; the result was shown the milk acidity was not affected by the treatment. The Mean overall average result indicated 0.2246 milk acidity. Whereas in treatment phase about 0.2213 milk acidity that means there was similar to control, there is no effect between the supplemented and the milk acidity. It also the same result in residual effect.

Therefore the overall result (Table 10) indicates that feeding Asparagus racemosus root powder was statistically highly insignificant $0.3909(P>0.1)$ probability level. While in each lacteted buffalo the treatments was not significant $M=0.357, B=0.907$, $\mathrm{MU}=0.625$ and $\mathrm{L}=0.357$ significant level. That mean no correlation (impact) between the treatments and milk acidity whereas $\mathrm{J}=0.084$ was significant level.

Determination of total milk solid was observed (table 11), out of five samples more than half of the number statistically insignificance 0.8904 ( $p>0.1$ ) effect on total milk solid. That means no difference between herbal diet and total milk solid whereas two of sample was negative relation between the herbal and total solid due to as the percentage of acidity increased the milk acidity was increased. While the one sample was shown significantly effect. Therefore ARRP had no influence on total milk solid. Therefore to conclude the effect ARRP of treatment on milk acidity statistically insignificant at $80 \%(0.8904)$ as compared to control.

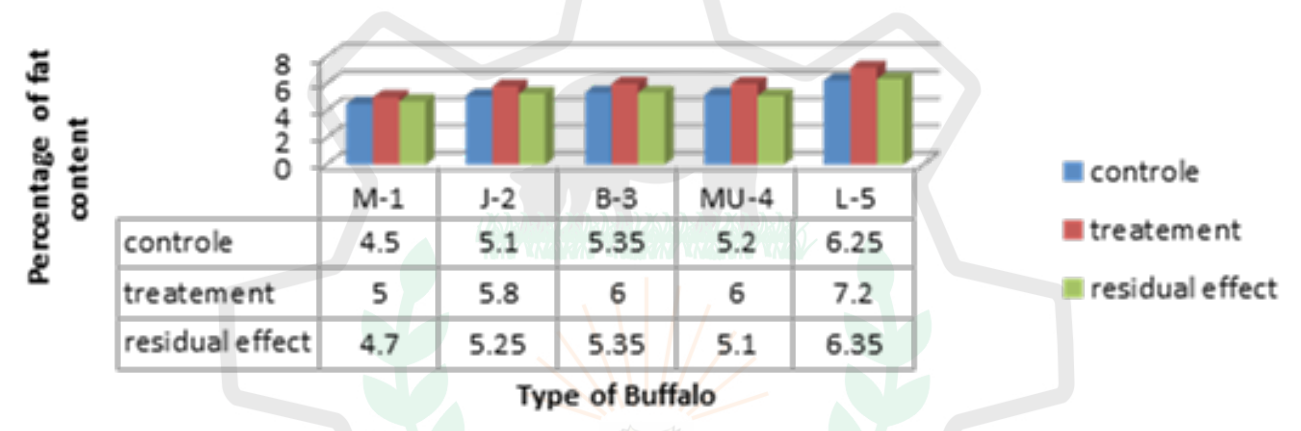

Figure 7: Effects of the Asparagus racemosus supplemented on milk fat content

Table 9: The mean value of milk acidity in control, treatments and residual phase

\begin{tabular}{lllllll}
\hline No & Breed & Control & Treatment & Residual & Difference & $\%$ \\
\hline 1 & M-1 & 0.2455 & 0.2465 & 0.245 & 0.001 & 0 \\
2 & J-2 & 0.3425 & 0.3255 & 0.32 & -0.017 & 0 \\
3 & B-3 & 0.2035 & 0.2035 & 0.206 & 0 & 0 \\
4 & MU-4 & 0.198 & 0.1975 & 0.198 & -0.0005 & 0 \\
5 & L-5 & 0.1335 & 0.1335 & 0.132 & 0 & 0 \\
& Mean & 0.2246 & 0.2213 & 0.2202 & & \\
\hline
\end{tabular}

Table 10: Analysis the Effects of ARRP on milk yield through ANOVA one way and T-test

\begin{tabular}{llllllll}
\hline & \multicolumn{1}{l}{ ANOVA one way } & \multicolumn{3}{c}{ T-test } \\
No & Buffalo & F-value & $p$-value & Sig & Milk character & t-value & $p$-value \\
\hline 1 & M-1 & 1.8 & 0.357 & Non & & \\
2 & J-2 & 10.87 & 0.084 & $*$ & & -0.961 & 0.3909 \\
3 & B-3 & 0.1 & 0.907 & - & Milk acidity & - & \\
4 & MU-4 & 0.6 & 0.625 & - & & \\
5 & L-5 & 1.8 & 0.357 & - & & \\
\hline
\end{tabular}

Table 11: Analysis the Effects of Asparagus racemosus root powder on milk yield through ANOVA one way and T-test

\begin{tabular}{|c|c|c|c|c|c|c|c|c|}
\hline \multirow[b]{2}{*}{ No } & \multicolumn{3}{|c|}{ ANOVA one way } & \multicolumn{2}{|r|}{$t$-test } & \multirow[b]{2}{*}{$t$-value } & \multirow[b]{2}{*}{$p$-value } & \multirow[b]{2}{*}{$\mathrm{Sig}$} \\
\hline & Buffalo & F-value & $p$-value & Sig & Milk character & & & \\
\hline 1 & $M-1$ & 1.14 & 0.467 & Non & & & & \\
\hline 2 & $\mathrm{~J}-2$ & 9.94 & 0.091 & * & & & & \\
\hline 3 & B-3 & 9.65 & -0.093 & $*$ & Total solid & 0.1467 & 0.8904 & - \\
\hline 4 & MU-4 & 2.23 & 0.309 & No & & & & \\
\hline 5 & $L-5$ & 236.4 & 0.004 & $* * *$ & & & & \\
\hline
\end{tabular}




\section{Discussion}

In the present study Asparagus racemosus are supplementing at the time of milking with normal diet increased milk yield of buffalo significantly. According to Patel, et al., 2016 observed the effective herbal galactogogue and its uses as feed additive in dairy animals improve livestock performance. Similarly (Dibya, 2010) and (Kumar et al., 2008) has been reported the effect of ARRP supplementing on milk yield were statistically significant. Asparagus racemosus is content some active substances effect on secretory cells of the mammary gland Johnsson, et al. (1985), (Ramesh, 2000) and (Kumar, 2014). The increasing of milk yield due to ARRP may contain some active component which are stimulating milk let down to increase milk secretion and direct action on the mammary gland to directly pituitary gland and antagonist dopamine receptor are increase in prolactin and ACTH (Jetmalani 1967, Sabnis 1969, Krishna 2005, Saini 2017) While the other enhance due to supply the required amount of mineral nutrition on lactating cow.

As Described (Saini, 2017) and (Marzioli, 1986) the effect of supplementing ARRP shows positive response that has been shown positive correlations between herbal root and milk protein concentration. According to (Dibya, 2010) and (Kumar, 2014) were observed in experiment in vitro show the effect on rumen microbial metabolism, which increases protein synthesis and efficiency of milk protein. (Broudiscou, 2002) and (Tedesco, 2004) also describe many herbs in test in vitro display the effect on rumen microbial metabolism, which more desirable protein synthesis and efficiency of yield of biomass manufacturing. Similarly (Johnsson, 1985) also observed the fine effects on milk production that may be obtained when periparturient dairy cows are fed a ration with a natural hepatoprotector. These indicated that a few lively materials in herbs affect secretory cells of the mammary gland.

According to (Dibya, 2010) and (Saini, 2017) described the increasing of milk fat content may be due to the rise of lipogenic activities. Diet and the status of the methanogenic population inside the rumen substantially greatly affect the percentage of fat. Likewise (Kumar, 2014) also study the effect of ARRP fed with balanced ration was influenced on milk fat percentage and also used for development of herbal preparation and bio-enhancer.

The milk acidity and total solid data was recorded during the treatment period; the result was shown the milk acidity and total solid was not affected by the treatment. That means the milk acidity there was not difference between the treatment and the control. According to (Dibya, 2010) (Saini, 2017) observed the ARRP had no statistically significant effect on milk acidity and total solid.

\section{CONCLUSION}

Generally the result indicates that the effect of ARRP as fed with ration was statistically significant effecting on milk yield at 5\% (0.0196), protein at 1\%(0.0113) and fat 1\% (0.0007) improved milk yield, protein content and fat content while insignificant effect on milk acidity (0.3909) and total solid (0.8904). Therefore, feeding Asparagus racemosus to lactating buffalo more advantageous and it help to improve the income of the dairy farmers as well as increased the nutrition value of the milk protein yield and fat yield.

\section{ACKnOWLedgement}

Authors thank Minister of Agriculture, Government of Ethiopia, Addis Ababa for providing scholar to study master of Biotechnology and financial support of the project

\section{Reference}

AOAC.(1990). Official Methods of Analysis. Association of Official Analytical Chemists Inc., Virginia, USA.

Behera, P. C., Tripathy, D. P., \& Parija, S. C. (2013). Shatavari: potentials for galactogogue in dairy cows.

Broudiscou, L. P., Papon, Y., \& Broudiscou, A. F. (2002). Effects of dry plant extracts on feed degradation and the production of rumen microbial biomass in a dual outflow fermenter. Animal Feed Science and Technology, 101(1-4), 183-189.

Dibya, K. K. (2010). Shatavari (Asparagus Racemosus Willd.) used as A Feed Supplement for Enhancing Production and Quality of Indigenous Cross Breed Cow's Milk (Doctoral dissertation, Indira Gandhi Krishi Vishwavidyalaya, Raipur).

F.A.O. Methods of test for Dairy Industry-Rapid Examination of Milk. Manual of Food Quality Control, IS 1479 (Part I) Bureau of Indian Standards, New Delhi, 1961.

ISO 6731, (1989). Milk, Cream and Evaporated milk. Determination of total Solids Content. Bureau of Indian Standards, New Delhi, 1989

Jetmalani, M. H., P. B. Sabins, and B. B. Gaitonde. A study on the pharmacology of various extracts of Shatavari-Asparagus racemosus (Willd). J Res Indian Med 2 (1967): 1-10.

Johnsson, I. D., Hart, I. C., Simmonds, A. D., \& Morant, S. V. (1985). Pre-pubertal mammogenesis in the sheep 2. The effects of level of nutrition on the plasma concentrations of growth hormone, insulin and prolactin at various ages in female lambs and their relationship with mammary development. Animal Science, 41(3), 333

Krishana, L., Swarup, D., \& Patra, R. C. (2005). An overview of prospects of ethno veterinary medicine in India. The Indian Journal of Animal Sciences, 75(12).

Kumar, S., Mehla, R. K., \& Singh, M. (2014). Effect of Shatavari (Asparagus racemosus) on milk production and Immunemodulation in Karan Fries crossbred cows.

Kumar, S., Mehla, R. K., \& Dang, A. K. (2008). Use of shatavari (Asparagus racemosus) as a galactopoietic and therapeutic herb-a review. Agric. Rev, 29(2), 132-138.

Lowry, O. H., Rosebrough, N. J., Farr, A. L., \& Randall, R. J. (1951). Protein measurement with the Folin phenol reagent. Journal of biological chemistry, 193, 265-275.

Marziali, A. S., \& Ng-Kwai-Hang, K. F. (1986). Relationships between milk protein polymorphisms and cheese yielding capacity. Journal of Dairy Science, 69(5), 1193. 
Patel, V. K., Joshi, A., Kalma, R. P., Parmar, S. C., Damor, S. V., \& Chaudhary, K. R. (2016). Shatavari (Asparagus racemosus), Jivanti (Leptadenia reticulata) and Methi (Trigonella foenumgraecum): the herbal galactogogues for ruminants. Journal of Livestock Science (ISSN online 2277-6214), 7, 231-237.

Pawar, S. D., Hande, S. T., \& Somkuwar, A. P. (2005). Role of herbal plants in enhancing milk production in dairy animals. Indian Dairyman, 57(6), 62.

Pehrsson, P. R., Haytowitz, D. B., Holden, J., Perry, C. R., \& Beckler, D. G. (2000).USDA's national food and nutrient analysis program: food sampling. Journal of Food Composition and Analysis, 13(4), 379-389.

Ramesh, P. T. (2000). Evaluation of Galactin, a herbal galactagogue preparation in dairy cows. group, 6(6.039), 5-563.

Sabins PB, Gaitonde BB, Jetmalani M (1969)."Effect of alcoholic extract of Asparagus racemosus on mammary glands of rats". Indian J Exp 6:55-57.

Saini, V. P. (2017). Effect of Herbal Feed Supplement Shatavari (Asparagus racemosus) on Nutrient Utilization and Milk
Production in Crossbred Cows (Doctoral dissertation, Rajasthan University of Veterinary and Animal Sciences, Bikaner).

Santosh, K., Mehla, R. K., Gupta, A. K., Sharma, V., Meena, R. K., Dandi, R. L., \& Anand, P. (2011). Effect of herbal feed supplement Shatavari (Asparagus racemosus) on milk production and composition in crossbred cows. Indian Journal of Animal Sciences, 81(4), 420-423.

Snedecor, G. W., \& Cochran, W. G. (1989). Statistical methods, 8thEdn. Ames: lowa State Univ. Press lowa.

Tedesco, D., Tava, A., Galletti, S., Tameni, M., Varisco, G., Costa, A., \& Steidler, S. (2004). Effects of silymarin, a natural hepatoprotector, in periparturient dairy cows. Journal of dairy science, 87(7), 2239-2247.

Turner, J. C., \& Davies, W. P. (2002, March). The modern food chain: profiting from effective integration. In Trade Partners UK and Ministry of Agriculture Modern Food Chain Seminar, Kuala Lumpur (Vol. 26, 1-37).

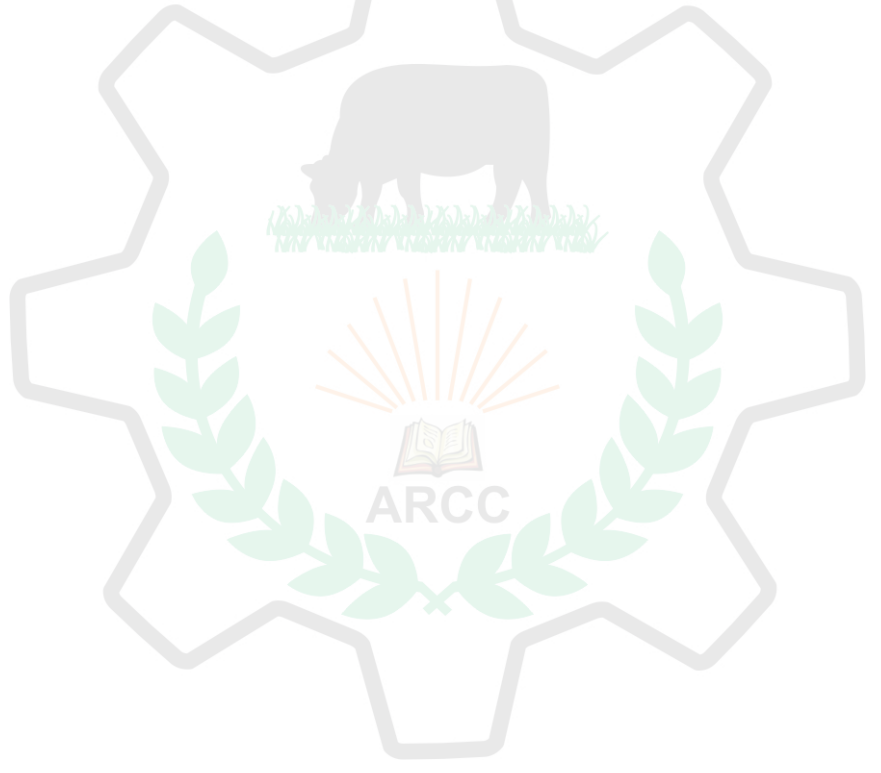

